\title{
Bcr-Abl Kinase Inhibitor K0706
}

National Cancer Institute

\section{Source}

National Cancer Institute. Bcr-Abl Kinase Inhibitor K0706. NCI Thesaurus. Code C132173.

An orally bioavailable, Bcr-Abl tyrosine kinase inhibitor (T KI), with potential antineoplastic activity. Upon administration, Bcr-Abl kinase inhibitor K0706 selectively targets and binds to the Bcr-Abl fusion oncoprotein, including various Bcr-Abl mutant forms, such as those with the 'gatekeeper' resistance mutation T315I. This inhibits proliferation of Bcr-Ablexpressing tumor cells. The Bcr-Abl fusion protein is an aberrantly activated tyrosine kinase produced by certain leukemia cells. T315I, an amino acid substitution where threonine $(T)$ has been mutated to isoleucine $(I)$ at position 315 in the tyrosine-protein kinase $A B L 1$ portion of the Bcr-Abl fusion protein, plays a key role in resistance to certain chemotherapeutic agents and its expression is associated with poor prognosis. 